\title{
ACTUAL ASPECTS OF THE PROBLEM OF INTERTEXTUALITY IN MUSIC
}

\section{Grybynenko Ju. O.}

\section{INTRODUCTION}

The dominant cultural trend of the second half of the $\mathrm{XX}$ - the beginning of the XXI centuries is the integration of the previous historical genre and style experience in music and the search for its new value and semantic context; that is why the musical culture of this period can be attributed to a special type of culture, the elements of which become whole cultural traditions, mythopoetic structures, sign systems of different eras. The stylistic complication of culture accompanies the expression of the semantic experience accumulated by it. It forces one to approach culture as a special kind of text, thus enhancing the cultural significance of the latter and, at the same time, revealing the importance of the need to study culture as a special information and communicative phenomenon, structural and semantic integrity.

The problem of the text, its specificity and organization is not traditional for musicology; rather, it is a field of semiotics, linguistics, and literary criticism. However, its relevance for musicologists is becoming increasingly apparent. This is confirmed by the ever-increasing interest in this problem in the publications of domestic musicologists, including those that appeared in the first decades of the XXI century. They testify that musicology follows the path of mastering the already accumulated scientific experience in related fields of humanitarian knowledge and is trying to develop its own methods for studying the text and its conceptual system.

The theoretical base of musical textology is developed in the works by M. Aranovskyi, L. Akopyan, A. Denisov, A. Kozarenko, E. Kotlyarevskaya, I. Kokhanyk, V. Moskalenko, I. Pyaskovskyi, A. Samoilenko, S. Shipa, L. Berezovchuk, L. Kazantseva, A. Kudryashova, L. Krylova, B. Katz, L. Dyachkova, A. Klimovitskyi and others. Two leading lines can be distinguished among them: in some studies, the immanent approach ("from the inside" of a musical composition) to the study of a musical text is taken as the basis. In others, attention is focused on the use by composers of various methods of textual interactions and intertextuality techniques. The consideration of the problem field of the second trend is especially relevant today, which is confirmed by gradually developing entire research areas that already have their own traditions: musical semiotics, developing the ideas of C. Pierce (V. Kholopova (Russia)); studies of musical semantics (L. Shaimukhametova (Bashkortostan)); the combination of structural and semiotic interpretation, 
which defines the text as the sign structure of the language process, and musicological and aesthetic interpretation, designating the text as a temporary space in which cultural meanings are born (S. Ship, A. Samoilenko, V. Moskalenko (Ukraine)); intertextuality, acting as an artistic principle, as a method of dialogue of cultures, as a mechanism for the texts interaction with each other, allows a new interpretation of already known musical compositions, since it itself varies the parameters of its perception and contributes to the activation of meanings in the infinite semantic field of historical and cultural content. Therefore, it is so important to determine the development paths and the specifics of intertextuality manifestation in music, which will allow us, first of all, to approach the deep-seated attitudes that form the corresponding phenomena of art and culture in general.

\section{The concept of musical text in modern domestic research}

One of the central problems of modern musicology is the problem of text in music. This is confirmed by more and more numerous recent multidisciplinary studies on various issues of text and its formation in musical art, as well as ongoing discussions that offer new, original views on this problem.

The main line in the field of text theory at the edge of the XX $\mathrm{XXI}$ centuries is the awareness of this most important art criticism category as universal, finding adequate methods and approaches to the study of various textual phenomena, the need to develop a methodology for textual analysis of modern musical creativity.

The problem of the text arises and begins to be actively discussed in the humanitarian knowledge of the second half of the XX century. Literary studies, linguistics, semiotics, and many other sciences have clearly shown themselves in the study of the new paradigm of thinking. Among the studies in the above-mentioned disciplines, two lines are traditionally distinguished: in some, the immanent approach to the text study is taken as a basis, attention is focused on its internal structure; in others, a representative approach dominates, in which the text is perceived as a special form of intertextual interactions, a kind of thesaurus, cultural codes combination, knowledge about the surrounding reality.

The text is one of the key concepts of modern humanitarian knowledge, which is used in semiotics, structural linguistics, philology, text philosophy, structural and generative poetics. The word text has a rather complex and ramified etymology. However, with its various interpretations, three semantic components (marker or representative) remain mandatory, due to which the text becomes the text. Firstly, it must be what is created, made by man, unnatural; secondly, the connectedness of the elements inside it is required; thirdly, just as importantly, the mastery of it is valuable. In accordance with these three meanings, the text is studied by textology, hermeneutics and 
poetics. Textology identifies canonical text from several variants, comments on its content and produces attribution. Hermeneutics deals with the interpretation of the text. The skill of building a text, the principles of its composition, is studied by poetics. A text can be understood very broadly as defined by the semiotics and philosophy of the text (for example, a city street is a text (or a collection of texts). But if you follow this path, then everything turns out to be a text and there is no room for reality. V. Rudnev writes that "reality is a text written by God, and text is a reality created by man"1

Many leading concepts of text theory were developed in the works of Y. Lotman. The researcher lays the following definitions in the basis of the text concept: firstly, expressiveness, which means, first of all, the fixation of the text in certain characters; secondly, delimitation, which encloses the text in the gap between two external borders; thirdly, structurality, which indicates that the text is inherent in the "internal organization that turns it at the syntagmatic level into a single whole" ${ }^{2}$. The scientist in his semiotic and linguistic studies emphasizes that the inclusion of literary, philosophical, ideological, political and everyday references in the text makes them an important component of its semantic structure, destroys the monologism of the text, reinforcing the features of "dialogicity".

M. Bakhtin, being the founder of the theory of dialogicity, proposes to consider any text as an open structure, "a kind of monad, reflecting in itself all the texts (in the limit) of this semantic sphere" and insists that the text "exists thanks to many other texts" ${ }^{3}$. This idea was developed in the works of R. Barth and J. Kristeva and was reflected in their concept of intertextuality. R. Barth's reflections on the problem of text and text formation lead him to the following statement - any work, like text, is always an integral part of a large cultural text ${ }^{4}$.

G. Gadamer, agreeing with the thought of R. Barth that a text, especially an artistic one, as an open structure exists thanks to many other previous texts. It defines this phenomenon as a sequence of signs that captures the substantial unity of something said - even in that case when it is alienated from the one who said it, and recorded by someone else ${ }^{5}$.

According to the opinion "the world is a text", "there is nothing outside the text" formulated in the era of post-structuralism by J. Derrida, the whole human culture is considered as a single text, included in Genesis. All created

${ }^{1}$ Руднев В. Словарь культуры ХХ века. М.: Аграф, 1997. С. 308.

2 Лотман Ю. Структура художественного текста. М.: Искусство, 1970. С. 69.

${ }^{3}$ Бахтин М. Эстетика словесного творчества. М., 1986. С. 283.

${ }^{4}$ Барт Р. Избранные работы. Семиотика. Поэтика. М.: Прогресс, 1994.

${ }^{5}$ Гадамер Х.-Г. Текст и интерпретация Гперевод Е.М. Ананьева]. Герменевтика и деконструкция [под ред. В Штегмайера, Х. Франка, Б.В. Маркова]. Санкт-Петербург: 1999. 
texts, in this case, on the one hand, basically have a single pretext, and, on the other hand, turn out to be intertexts, since they become cultural phenomena ${ }^{6}$.

So, the definitions of the text in modern humanitarian knowledge are rather vague and generalized. This makes us talk about the lack of alignment of the main positions of the theoretical base of textology. However, despite this, one can notice common features in the definition of the text, namely: complexity, polyplasticity, hierarchy, openness, in the words of R. Barth "endless openness". The text is formed as a plurality of compositional embodiments of the same meaning (of the same group of semantic meanings), and, at the same time, a plurality of semantic meanings of the same compositional device. Musicologists are inclined towards such an understanding of this phenomenon.

Among the works in this area, the works of M. Aranovskyi, A. Akopyan, and A. Samoilenko stand out. Relying on A. Akopyan, we can say that the primary pole of the text is formed by a system of signs associated with the "universal constants" of musical culture (as a text), and the secondary is an individual unique, as its design, author's meaning. "The movement from the surface structure of a musical text to the depths of its immanent meaning implies a gradual distraction from the empirical text (surface structure) and, ultimately, rests on the deepest structural layer, which makes up the universal constants of psychology of the unconscious. At this level of abstraction, where the boundary between music and other manifestations of the creative potential inherent in the human psyche is blurred, and the analysis is in contact with the relationships that make up the last, most fundamental instance of those that dictate the characteristics of the corresponding empirical material" ${ }^{7}$.

$\mathrm{M}$. Aranovskyi considers the musical text as "a sound sequence that is interpreted by the subject as relating to music; it is a structure built according to the norms of some historical variety of musical language, and it carries one or another intuitively comprehended sense" ${ }^{8}$. This definition, in our opinion, is rather cumbersome and requires numerous explanations from the author, the purpose of which is, first of all, to specify the meaningfulness of a particular phrase (for example, a sound sequence). The researcher points out that all musical texts form a "vertical paradigmatic structure, where each new text is equivalent (according to certain signs) to the previous ones", "musical texts (and compositions) ... do not continue, but repeat each other" ${ }^{9}$.

A. Samoilenko agrees with the position of M. Aranovskyi that reflects the dual nature of the text - "to be constant, equivalent to oneself and, at the same time, produce new things" - and on the basis of these paradoxical

${ }^{6}$ Деррида Ж. О грамматологии [пер. с фр. и вступит. ст. Н. Автономовой]. М.: Ad Marginem, 2000. C. 318.

${ }_{7}^{7}$ Акопян Л. Анализ глубинной структуры муз текста. М.: Практика, 1995. С. 6.

${ }^{8}$ Арановский М. Музыкальный текст: структура и свойства. М., 1998. С. 35.

${ }^{9}$ Самойленко А. Музыковедение и методология гуманитарного знания. Проблема диалога: Монография. Одесса: Астропринт, 2002. С. 76-77. 
properties defines other properties of the text: transitivity and equivalence. The first facilitates the transfer of structural and semantic features of the text from one set of stylistic figures through second to the third. The second is associated with the operational mobility of a musical text, arising from the equating of various structural and semantic units ${ }^{10}$. Considering the text as a set of semantic representation results, as a plurality of incarnations of the same meaning, A. Samoilenko offers a dual semantic typology of music - "from the side of reception, structural and compositional autonomy and typification of musical semantics" and "from the side of meaning - aesthetic autonomy and value universality of musical semantics"11. Based on the author's thoughts, the ways in music from sense to text and from text to meaning are realized in a similar way. It is the path of music as a form of comprehension that suggests that the text and composition in music have a common historical path. The composition as a "text act" has completeness, creating internal borders in the text. It is "biased in its compositional semantics"12. For the text, all semantic meanings and techniques are equal and open in their capabilities. The composition acts as the unity of the compositional embodiment of various semantic meanings - as a "game" with meaning, and the text as a "game" with compositional rules.

The researcher's appeal to the methodological side of textology reveals the paradoxical features of the logic of the text, which are expressed in the coexistence of unchanging and changing, repetition and updating, updated repetitions and repeating updates, approach the leading concept of textology as a "specially ordered, hierarchical, structured, system-functional unity of musical meanings and their iconic carriers" ${ }^{13}$.

\section{Theoretical background for the formulation of the problem of intertextuality in music}

The development of the fundamental principles of Bakhtin's theory in the late 1960s led to the appearance in the French semiotic school of the theory of intertext, intertextuality. Introducing these terms into scientific use, Julia Kristeva designated with them traces of earlier texts in the subsequent. This concept has received wide resonance in modern linguistics and literary criticism, and these terms have indeed proved to be a successful replacement for such descriptive names as influences, borrowings, repulsions, etc.

Despite the fact that various manifestations of intertextuality have been known for a long time, the emergence of the corresponding term and theory in

${ }^{10}$ Самойленко А. Музыковедение и методология гуманитарного знания. Проблема диалога: Монография. Одесса: Астропринт, 2002. С. 158.

${ }^{11}$ Ibid. C. 151.

${ }^{12}$ Ibid. C. 150.

${ }^{13}$ Ibid. C. 116. 
the last third of the XX century is not accidental. The significantly increased availability of art works, the development of mass media and the spread of mass culture contributed to the intensification of the semiotization of human life and the feeling that, in the words of the Polish paradoxist Stanislav Jerzy Lets, "everything has already been said. Fortunately, not everything is thought of" art, and from some point on the everyday semiotic processes in the $\mathrm{XX}$ century, become largely "intertextual".

Just as semiotics - the science of the general properties of sign systems - was formed in the process of studying natural language, the theory of intertextuality developed mainly during the study of intertextual connections in fiction. However, in reality, the spheres of existence of intertextuality are much wider. Firstly, it is inherent in all verbal genres, and not just graceful literature. Secondly, it takes place not only in verbal texts, but also in texts created using other sign systems. Intertextual links are established between works of art, architecture, music, theater, and cinema.

Many leading concepts of the theory of intertextuality were developed in the works of Russian structuralists and poststructuralists, in particular, Y. Lotman and scientists of the Tartu-Moscow school. Thus, defining the boundaries of the text, Y. Lotman comes to the conclusion that the inevitability of any text being connected with others, the inevitability of dialogue and polylogue between texts of not only one era and not only belonging to the same art form, but also far removed from each other by time, genre or another scale. "The text does not exist by itself at all; it is inevitably included in any (historically real or conditional) context... That historical and cultural reality, which we call the "art work", is not limited to the text. The perception of a text divorced from its "extra-textual background" is impossible"14.

One of the leading works in the field of intertextuality is the essay of the French cultural historian and structuralist Roland Barth, "Death of the author". It proposes the rationale for the multidimensionality of any text existence. According to the French culturologist, the text "is not a linear chain of words, but a multidimensional space, where various types of writing are combined and arguing with each other, none of which is the source" ${ }^{15}$. The author refers to the fact that the word "text" etymologically implies a certain "fabric", "network", which is formed from "anonymous, elusive and yet read quotes without quotes"16. A follower of R. Barth, L. Jenny confirms this idea, noting that the main property of intertextuality is the introduction of a new way of reading, which explodes the linearity of the text. Each

14 Лотман Ю.Лекции по структуральной поэтике. Ю.М. Лотман и тартускомосковская семиотическая школа. М.: Гнозис, 1994. С. 203-204.

${ }^{15}$ Барт Р. Избранные работы: Семиотика: Поэтика: пер. с фр. [сост., общ. ред. и вступ. ст. Г. Косикова]. М.: Прогресс, 1989.С. 387.

${ }^{16}$ Ibid. C. 418. 
intertextual reference contains an alternative, consisting in the fact that it is possible either to continue reading without distinguishing this fragment of the text from others, or to return to the text the quotation source.

In his article "Problems of Intertextuality", I. Arnold focuses on such evidence of intertextuality as quotes, allusions, and entire introductory texts (text in text). Using the concept of the semiosphere proposed by Y. Lotman, the author explains the difference between literary influence and intertextuality: two phenomena have a common cause, since the semiosphere ensures the continuity of cognition of the world, however, the direction of the intertextual analysis is different. "Exploring intertextuality ... we look at what has got into the text, what readers will see in it, and what associations these inclusions can cause" ${ }^{17}$.

Therefore, by studying influences, we study the process of creating compositions, and by studying intertextuality, we consider traces of these influences, the author claims. An interesting difference is the researcher linguistic and textual manifestations of intertextuality. The first include the presence of different functional styles elements in the text. The second implies the presence of reminiscences, allusions and quotes, that is, any intext. The author also suggests highlighting (distinguishing) external and internal intertextuality, but does not argue convincingly enough for the difference between these forms of intertextuality.

In the monograph "Metaphor and Intertext in English Poetry" I. Tolchilin, generally sharing the position of I. Arnold, focuses on the existence in the reader's mind of certain "thesaurus", which reflects knowledge about cultural phenomena. The author connects the phenomenon of intertextuality with the action of this thesaurus, which is defined as the interaction between a text with a semantic structure and the reader's thesaurus, which represents a kind of learned texts dictionary ${ }^{18}$.

Thus, J. Kristeva and her followers put forward the concept of intertextuality, which is crucial for postmodernism, meaning special dialogical relations of texts that are based on a mosaic of quotes.

The identification of "alien" texts, "alien" discourses in the composition of the analyzed work, the definition of their functions is an intertextual aspect of its consideration. The correlation of one text with others (in their broad sense), which determines its semantic completeness and semantic multiplicity, is called intertextuality. Broadly speaking, intertextuality is understood as a universal property of text (textuality) in general. This approach involves considering any text as an intertext. In accordance with this understanding,

17 Арнольд И. Проблемы интертекста. Вестник СПбУ. СПб., 1992. Серия 2, выпуск 4. С. 53. СПбУ, 1996.

${ }^{18}$ Толчилин И. Метафора и интертекст в англоязычной поэзии. СПб.: Издательство 
the pretext of each individual work is all the specific preceding texts and the underlying common codes and semantic systems. Between the new texts being created and the previous "alien" there is a common intertextual space that includes all cultural and historical experience.

In accordance with a narrower approach, intertextuality does not mean a property of texts, but a special quality of only certain texts (or types of text). In this case, intertextuality is understood as such dialogic relations in which one text contains specific and explicit references to previous texts. Moreover, not only the author intentionally and consciously includes fragments of other texts in his text, but the addressee correctly identifies the author's intention and perceives the text in its dialogical correlation.

In general, we can conclude that intertextuality in the second half of the $\mathrm{XX}$ and beginning of the XXI centuries becomes a methodological prerequisite for "reading" and interpreting (understanding) cultural phenomena and art works (any text). It is one of the ways and means of transmitting information. "An author's composition is inevitably perceived as the intersection of various quotes and allusions, a representative and connotator of a comprehensive mass of cultural meanings, which Barth indicated with the term Big Text"19.

As a system of text interaction, the sphere of intertextuality functioning always provides the interaction of "one's own" and "another's" text, which makes it possible to perceive it as a special way of including human consciousness in the process of understanding cultural reality. To understand the essence of intertextuality, a typology of this phenomenon is proposed, based on the tendency of the author's evaluative choice, namely, the following are distinguished:

- selective and summarizing tendencies - from the position of the volume and general boundaries of textual material;

- ordering and chaotic tendencies - from the position of structuring textual material;

- emphasizing the value-significant side of textual material and denying its tendencies - from the position of textological material comprehension.

\section{Stylistic tricks as a means of forming intertextual links}

So, intertextuality as a condition and way of text existence in a semiotic cultural environment relative to the compositional process of an individual artist acquires the significance of methodology. The versatility of intertextuality in music shows the creative method of a variety of composers, among which there are L. Berio, D. Ligeti, P. Boulez, A. Schnittke,

19 Высоцкая М. К проблеме интертекстуальности в музыке Фараджа Караева. Музыкальное искусство в современном социуме: сб. научных статей [ ред.-сост. А. Крылова]. Ростов н/Д.: РГК имени С.В. Рахманинова, 2014. С. 149. 
V. Silvestrov, B. Tishchenko, E. Denisov, F. Karaev, V. Tarnapolskyi and many others. At the same time, each author has his own codes, techniques, and his own technologies for building intertextual relationships.

The intertextual elements in the composition of the art work are diverse - this is a whole scale of techniques with different "range of action", different semiotic functions: this is a quote, allusion, stylization, collage (this list, which is traditional for the characterization of intertextual interactions, is expanded by M. Vysotskaya, who supplements it with anagramming and transcription, and $\mathrm{M}$. Romanets, who introduces also the principle of auto-quotation). The listed forms of intertextual interactions constitute the most important component of modern composer poetics, while also acting as a generator of text semantic productivity (J. Kristeva) of contemporary art as a whole. Because, in the words of M. Yampolskyi, they are like atoms in space, where, as in the divine completeness and nonrevealing, there is an entire wealth of meanings.

Here we consider three methods of intertextual links - quotation, allusion, and stylization, as the most explicit methods of intertextual borrowing, which indicate the degree of their remoteness from the stylistic source. The criterion for their choice is determined, first of all, by the correlation of "their own" and "alien" in the text of the work: from submission to the authority of the "alien" - through the development of its logical apparatus - to self-legality in relation to it, to the transformation of "alien initiative" into one's own.

According to encyclopedic definitions, a quote is a verbatim reproduction of piece of a text, someone else's material, creating the effect of stylistic or genre contrast and acting at different levels of the text. The quote, according to philologists, contributes to the imagery, expressiveness and capacity of musical speech; it allows you to economically and deeply characterize the phenomena of reality through parallels with artistic images of world art, mythology, folklore. Being aphoristically brief and elegant in form, it evokes the idea of the whole from which it is extracted, as if replacing or concentrating a complex image embodied in an art work. Through a quotation "preserving the old emotionality" (Y. Tynyanov), the previous artistic experience enters, involving the knowledge of texts from a recipient, sensitive to associations and hints.

The concept of quotation has long been included in the scientific usage of musicologists, not as a strict term, but as a metaphor. In the literary and musical fields, quotation retains some of its main characteristics. Both there and here the quote is a fragment of a different origin introduced into the author's text. Both there and here the quote is a literal reproduction of someone else's text. "However, in relation to music, it is quite acceptable to call a quote without special reservations what is actually a "free retelling", if 
only the illusion of a complete style coincidence with the original source would arise. Both there and here, under the guise of a genuine quote, quasiquotation may be introduced" 20 .

Firstly, the quote should be compact, otherwise it will not be an additional element of the author's speech, but the main subject of attention, that means, it will cease to be a quote. Secondly, in the design of the quotation, the initial and final moments should be clearly expressed, so the quote requires prior notice. Thirdly, the quotation receives a certain author's interpretation (it can be an object of criticism, an object of praise, a confirmation method based on the power of authority, etc.). A vivid quotation effect arises only with the intonation prepared inclusion of a relatively small foreign style fragment; in all cases of non-monologic unfolding of musical fabric - in dialogues, opera scenes, according to E. Nazaykinskyi, the possibility of internal quotes is practically excluded - a brief replica intrusion of one of the two opera actors into the singing of the other can not be called a quote, although the stylistic contrast may be similar ${ }^{21}$.

Quotation thinking is very characteristic of the work of postmodernists, since the vital feeling of their own intertextuality is the internal style of postmodernism, which seeks to express its sense of "cosmic chaos" with chaos of quotes, where the "process of the disintegration of the world of things" reigns ${ }^{22}$.

An allusion is an easy hint of a chosen style model. "This is a stylistic figure, a hint of a historical event or a piece of music that is supposed to be well-known. This is the presence of such elements in the text, the function of which is to indicate the connection of this text with other texts or to refer to certain historical, cultural and biographical facts. Such elements are called markers or representatives of allusion, and the texts and facts of reality to which reference is made are called denotations of allusion. The denotation of allusion can be not only verbal texts, but also "texts" of other forms of art. Such allusions are called inter-medial" ${ }^{23}$.

A text allusion differs from a quotation in that the elements of the pretext (that is, the preceding text to which the text refers) in the text are dispersed and do not represent a holistic utterance or implicitly. Very often it is implicitity that is considered to be the defining property of allusion, and therefore there is a tendency to use this term only if some understanding and special knowledge are needed to understand the allusion. Moreover, these elements of the donor text, to which allusion is carried out, are organized

\footnotetext{
${ }^{20}$ Назайкинский E. Стилистика музыкального произведения. URL: www.harmony.musigi.dunya.az/harmony/rus/

${ }^{21}$ Ibid.

${ }^{22}$ Hassan I. Paracriticism: Seven speculations of the times. Urbana, 1975. XVIII. P. 59.

${ }^{23}$ Аллюзия. URL: https://www.krugosvet.ru/enc/gumanitarnye_nauki/lingvistika/
} ALLYUZIYA.html. 
in such a way that they turn out to be clutch nodes of the semantic and compositional structure of the recipient text. "The principle of allusion is manifested in the subtlest hints and unfulfilled promises on the verge of quotation - but without stepping over it" ${ }^{24}$.

Allusions can be typologized by the degree of their attribution, namely, by whether the intertextual connection turns out to be a specially designated factor of the author's construction and reader's perception of the text or not. So, textual allusion creates a "pseudo-author" basis for a reminiscence attitude. This may include the principle of adaptation of someone else's text - a kind of retelling of the musical text with its own musical language. For example, this process is clearly shown in the Second Violin Sonata by A. Schnittke, where the composer relates the Beethoven material (the ending of the Third Symphony and piano variations op. 35) with the dramatic situation in the sonata. This is what makes the composer not exactly repeat the "words" of L. Beethoven, but only reproduce the morphological side of the text of the Viennese classic, against which new meanings arise. A similar situation is observed in I. Stravinskyi in "Pulcinella", in R. Shchedrin's "Carmen Suite". A. Schnittke in "Dedication to Paganini" also uses this principle, but from an interesting angle - the angle of a receding perspective: explicit allusive material, appealing to the works of the famous violinist virtuoso, smoothly transfers into a situation characterized by such an organic penetration of elements of his own and that of others, that there is a danger of dispersion (erasing) of the borders dividing these spheres.

This also includes the phenomenon of monogram motifs in composer poetics. The top lines of the popularity rating in the XX century are held by the BACH motif-monogram, which modern composers use both in a constructive and intonational sense (BACH represents one of the typical micro-frets of the present, it can be harmonized tonally, a series can be made, micro-intervals can be applied, etc.). At a point called BACH, the value of J.S. Bach-man, a music creator, and "Bach" as a kind of symbol of the history of music.

Vivid and revealing in this regard was the composition of A. Schnittke, "The Canon of Memory of Stravinskyi". At the heart of the composition there is a melody composed of musical sounds of the name, patronymic and surname of I. Stravinskyi (gfedeschesaes), which actually serves as the key to the composition sense. Paradoxically, two other monograms (D. Shostakovich and A. Schnittke) are hidden in this monogram, but the composer makes sure that the letters of these motifs do not appear nearby throughout the composition and thereby do not overestimate the semantic orientation of "The Canon". Named allusion sometimes acts as reminiscence. Reminiscence

${ }^{24}$ Холопова В., Чигарева Е. Альфред Шнитке: Очерк жизни и творчества. М.: Советский композитор, 1990. С. 328. 
refers to a reference not to a text, but to a certain event from the life of another author that is certainly recognizable.

Geographic names (toponyms) also become allusive elements connecting life facts and texts about them. In composing poetics, this aspect can be correlated with the moment of ethnic, national. The concept of national style, national specificity, national character are integrated by I. Lyashenko in a single concept of "national identity", which is considered in the context of two factors - external (relatively stable community of specific socio-ethnic groups psychology) and internal (direct reflection of the people's life). Both groups of factors were defined as style-forming patterns and national traditions.

The ability to carry an allusive meaning is possessed by elements of not only the lexical, but also the "grammatical" (syntagmatic) phonetic, metric levels of organization of the text; punctuation (in its musical expression), articulation and "spelling" as a degree of correctness, rigor or freedom of musical material organization can also serve the purposes of expressing this meaning. The latter includes the "golden horn move" (cello sonata by A. Schnittke), the theme perpetum mobile (built on the type of a developing spiral), the theme-circle (second intonations, structural symmetry, rotational type of melody, etc.), cadence, principles of sonatas and some others.

The ability to carry an allusive meaning is possessed by genre nominations and related author's comments and remarks introduced into the musical text. Modern composer poetics convincingly demonstrates two main trends in music from the turn of the XX to the XXI centuries, namely, the use of traditional genre nominations and the composer's need for new genre forms or for a radical renewal of the old ones. So, G. Ustvolskaya, for example, does not introduce catchy genre nominations (the exception is "Compositions") as, for example, V. Silvestrov does it. However, a new style interpretation of traditional genre forms (preludes, sonatas, symphonies) leads to their complete destruction - re-arrangement. Genre forms in the compositions of Odessa composer Y. Gomelskaya are original and do not fit into any of the traditional canons. Many of her compositions for the chamber ensemble are striking in their diversity not only in terms of instrumental compositions, which is one of characteristic features of modern composer poetry, but also in terms of the symptomatic nature of the names of a number of compositions. The interpretation of allusions, as well as any intertextual relationship, implies that the author and the recipient have some general knowledge, sometimes very specific. Often, composers build allusions in their works, appealing to texts written either long ago or belonging to little-known ones, which complicates the search for the denotation of allusion.

Stylization is a technique involving the most accurate creation of chosen style model features (style of an era, an artistic direction or an individual author) with a certain degree of rethinking the norms of someone 
else's style in the context of the language norms of a new era and a different author's style. The components that form the stylistic structure of the composition are not only very heterogeneous, but they are combined in different ways in the artistic whole. According to E. Nazaykinskyi, here we can talk about three specific dimensions of stylization. Temporary deployment, which is characterized by comparisons and smooth connections of various components, is a horizontal, peculiar stylistic relief of development. But it can be supplemented with a vertical - clearly audible stylistic polyphony, that is, the simultaneous action of two or more stylistically independent components. We call this measurement a vertical by analogy with the sound-pitch organization of a polyphonic texture ${ }^{25}$.

Stylistics also has an in-depth dimension. After all, the individual handwriting of the composer lying on the surface of the style phenomenon of music is only the first layer. Moving deeper, we can, in an individual manner, discover features of the style of a particular school, era, national culture, and features of the genre style. In its deepest dimension, stylistics appears as special synchronous bedding. Accordingly, the elements that make up a style are defined differently. Horizontally, fragments, constructions, and episodes with one or another stylistic characteristic are connected to each other. Vertical are stylistically personified lines. The deep structure is most often represented as a hierarchy of layers or plans. It is central to styling.

Supporting and developing the thoughts of E. Nazaykinskyi, S. Ship suggests stylizing an appeal to the expressive means of at least two styles representing the "external" and "internal" artistic positions. There are several ways to achieve stylized musical and linguistic interaction: the first method consists in sequentially pairing different styles of musical speech (direct comparisons, style switching, as well as smooth transitions, transformations, modulations from one style to another are possible here); the second method is determined by the simultaneous pairing of expressive means belonging to different styles. To clarify this, it is necessary to imagine the organization of musical form in the form of a hierarchical system. At system levels and sublevels, simultaneous manifestation of signs of different styles is possible. The third way to perform stylization is through the interaction of monostyle musical means and some extra-musical-formal components of the work (titles, programs that focus on other stylistic phenomena). Examples of this kind are extremely rare, since it requires the composer to have a special ability to "play" with the perception of the recipients, who in turn should be aware that the author's own artistic position is different from that presented ${ }^{26}$.

${ }^{25}$ Назайкинский E. Стилистика музыкального произведения. URL: www.harmony.musigi.dunya.az/harmony/rus.

${ }^{26}$ Шип С. Стилизация как художественно-выразительный прием в современной украинской музыке. Проблемы музыкальной культуры. К.: Музична Україна, 1989. Вып. 2. 
Based on the foregoing, we can conclude that composer work with intertext can be of a different nature, but the tasks, first of all, are in expanding the capacity of the literary text, formation of deep semantic "overtones", semantic polyphony, in which "other people's voices" find their place, embedding in the author's context.

\section{CONCLUSIONS}

A musical composition can be represented in the form of an author's contamination of quotes and allusions insofar as the linguistic musical activity leads to the fact that its iconic structures appear mainly from the style and stylistic side. It is precisely the "squeezed" style marks that musicologists usually call the "keywords" of composers of the second half of the XX and the beginning of the XXI centuries. And the list also includes the "sayings" of composers of past eras, opened by aphoristic quoting, and in the form of "hidden dialogue", which can only be noticed deeply studying the proposed composition. A musical composition does not exist by itself, but at the expense of many other works that were created earlier or in parallel with it. Accepting the thought of G. Gadamer about the text, it can be argued that any composition as a text is always an integral part of the Great Cultural Text, for which intertextual relations are always necessary and relevant. Thanks to the last one, texts (or fragments of texts that are included in a composition by its constituent parts) become semantically adjacent. As a result, thanks to the creative personality of the author, rethinking and updating them, the texts become, in the words of R. Barth, "infinitely open to space".

Intertextuality can be considered as a universal property of music, an objective regularity of the development of musical thinking and musical language. Dialogue / polylogue by means of intertextuality occurs not only between texts and styles, but also between sets of types of cultures, sets of cultural codes, the existence of which the author sometimes does not even suspect, since the phenomenon of intertextuality is closely connected with the unconscious. Thanks to reliance on "intertext", the composition becomes an open structure, and such an "open work" (this concept becomes the title in the last book of Umberto Eco) cannot be final.

Thus, we can say that intertextuality is directly related to references as the rules for choosing the material that you need to know, and this connection allows us to determine general trends and methods of composer work with text, namely:

- assimilation (consent, removal of the author's distance in relation to "someone else's textological material));

- discrepancy (exclusion, partial distance in relation to "someone else's textual material);

- identification (removal, rejection of the "alien", up to alienation); 
- rejection (active rejection, deformation, breaking the borrowed stylistic model).

\section{SUMMARY}

The concept of this article is based on the textological trends of modern humanitarian knowledge, which clearly show themselves in the theory of intertextuality. The fundamental importance of the composer's use of various methods of textual interactions and intertextuality techniques is emphasized. This allows to discover ways of the mutual transition of "one's own" "another's" in music.

The main approaches that have developed in relation to the phenomenon of intertextuality in modern humanitarian knowledge are determined, as well as related literary and musicological positions in the field of intertextuality theory; a typology of intertextuality is proposed in terms of its textual, aesthetic (value), compositional and artistic characteristics.

It is offered to interpret stylistic techniques - quotation, allusion, and stylization - as a means of intertextual translation, as a manifestation of intertextual interactions. This allows to a certain extent to decode the work of the author.

The method of composer creativity in the second half of the XX and the beginning of the XXI century is largely due to the information glut of musical culture; the theory of intertext as a special information and communicative phenomenon allows one to adequately interpret the interaction, ways and features of the translation of entire information layers, thus contributing to an understanding of the complex cultural situation at the turn of the century.

\section{REFERENCES}

1. Акопян Л. Анализ глубинной структуры муз текста. М.: Практика, 1995. 256 с.

2. Аллюзия. URL: https://www.krugosvet.ru/enc/gumanitarnye_ nauki/lingvistika /ALLYUZIYA.html.

3. Арановский М. Музыкальный текст: структура и свойства. M., 1998. 343 c.

4. Арнольд И. Проблемы интертекста. Вестник СПбУ. СПб., 1992. Серия 2, выпуск 4. С. 49-57.

5. Барт Р. Избранные работы: Семиотика: Поэтика: пер. с фр. [сост., общ. ред. и вступ. ст. Г. Косикова]. М.: Прогресс, 1989. 616 с.

6. Бахтин М. Эстетика словесного творчества. М., 1986. 445 с.

7. Высоцкая М. К проблеме интертекстуальности в музыке Фараджа Караева. Музыкальное искусство в современном социуме: сб. научных статей [ред.-сост. А. Крылова]. Ростов н/Д.: РГК имени С.В. Рахманинова, 2014. С. 149-166. 
8. Гадамер Х.-Г. Текст и интерпретация [пер. Е.М. Ананьева]. Герменевтика и деконструкция [под ред. В. Штегмайера, Х. Франка, Б. В. Маркова]. Санкт-Петербург: 1999. С. 202-242.

9. Деррида Ж. О грамматологии [пер. с фр. и вступ. ст. Н. Автономовой]. М.: Ad Marginem, 2000. 512 c. 1970. $384 \mathrm{c}$.

10. Лотман Ю. Структура художественного текста. М.: Искусство,

11. Лотман Ю.Лекции по структуральной поэтике. Ю.М. Лотман и тартуско-московская семиотическая школа. М.: Гнозис, 1994. С. 11-265.

12. Назайкинский Е. Стилистика музыкального произведения. URL: www.harmony.musigi.dunya.az/harmony/rus

13. Руднев В. Словарь культуры ХХ века. М.: Аграф, 1997. 384 с.

14. Самойленко А. Музыковедение и методология гуманитарного знания. Проблема диалога: Монография. Одесса: Астропринт, 2002. 244 с.

15. Толчилин И. Метафора и интертекст в англоязычной поэзии. СПб.: Издательство СПбУ, 1996. 96 с.

16. Холопова В., Чигарева Е. Альфред Шнитке: Очерк жизни и творчества. М.: Советский композитор, 1990. 350 с.

17. Шип С. Стилизация как художественно-выразительный прием в современной украинской музыке. Проблемы музыкальной культуры. К.: Музична Україна, 1989. Вып. 2. С. 86-105.

18. Hassan I. Paracriticism: Seven speculations of the times. Urbana, 1975. XVIII, $184 \mathrm{p}$.

\section{Information about the author:} Grybynenko J.,

Ph.D. in the History of Art, Assistant Professor of the Department Of Music History and Musical Ethnography, Odessa National A. V. Nezhdanova Academy of Music 63, Novoselsky str., Odessa, 65023, Ukraine Orcid: https://orcid.org/0000-0003-4891-5157 